\title{
THE ORGANIZATION OF INDEPENDENT WORK STUDENTS WHEN TEACHING INVERSE PROBLEMS FOR DIFFERENTIAL EQUATIONS
}

\author{
V.S. Kornilov \\ Moscow city pedagogical university \\ Sheremetyevskaya str., 29, Moscow, Russia, 127521
}

\begin{abstract}
The article notes that extracurricular independent work makes a great contribution to the development of students' scientific and cognitive potential in the process of learning inverse problems for differential equations. In the process of independent work, students not only study the educational and scientific material on inverse problems, given in the classroom, but also studied the special scientific literature, that is, scientific articles, materials of scientific conferences, published not only in Russian but also in English. At the same time, students master the scientific style of presentation of scientific material in such special literature, which differs significantly from the style of presentation of educational material in University textbooks. It is noted that during the independent work students explore a variety of inverse problems that are recommended to them by the teacher. They develop skills and abilities to independently formulate logical conclusions based on the results of the study of inverse problems.
\end{abstract}

Key words: learning inverse problems for differential equations, independent work of students, mathematical creativity of students, scientific and cognitive potential of students

Independent work of students of higher educational institutions is an important educational activity that contributes to the formation of a system of fundamental subject and scientific knowledge (see, for example, $[1 ; 5 ; 6 ; 21 ; 24]$ ). Independent work of students is carried out in extracurricular time. In the work programs of academic disciplines teachers should be prescribed hours and topics for independent work of students. Their number should be agreed with the heads of departments and Dean's office, in order to avoid academic overload students. Teachers should develop and coordinate schedules with students.

Currently, some Russian universities for students of senior courses of physical and mathematical directions of preparation are taught elective courses devoted to inverse problems for differential equations (see for example, $[2 ; 8 ; 12-19]$ ). The content of learning inverse problems for differential equations is formed on the basis of the theory of inverse and ill-posed problems, which is one of the scientific directions of modern applied mathematics (see, for example, [3; 4; 7-11; 20; 22; 23]). Since inverse problems are, as a rule, incorrect problems, the search for non-template solutions which involves a deep analysis of the physical process under study and its cause-and-effect relationships, these circumstances suggest that students of rational thinking and creative approaches both to build a system of integral equations of inverse problems, and in the future to prove theorems of existence, uniqueness and conditional correctness of the solution of inverse problems. 
The above requires from students not only conscientious attitude to learning in the classroom subject knowledge on inverse problems for differential equations, but also a lot of independent work, which requires perseverance, curiosity, activity, mathematical creativity. At the same time, a great responsibility in the implementation of independent work is assigned to the teacher, leading such training sessions. During their independent work, students investigate the correctness of decisions of various inverse problems that are recommended to them by the teacher. They develop skills and abilities to independently formulate logical conclusions based on the results of the study of inverse problems.

Students may be asked, for example, to work on their own:

- perform mathematical calculations that do not require new knowledge of inverse problems that were omitted in the lecture;

- solve the inverse problem for a differential equation or another mathematical problem logically related to the described sections of inverse problems;

- read a specific scientific article on inverse problems for differential equations, which is the formulation and method of the study is close to the previously discussed in the lecture, to understand the method of its solution, to analyze the physical meaning of the most applied problems, to Express their views on the merits and advantages of the article approach to its solution.

We present approaches to the implementation of independent work of students in the learning process of inverse problems for differential equations.

Participation of students in scientific seminars on inverse problems for differential equations. This practice is implemented in a number of Russian classical universities, where departments operate on the basis of research institutes, for example, at the Novosibirsk state University. These seminars discuss new research results on the inverse problems of the employees of these research institutes, who are also teachers of these students. Visiting the seminars, students not only get acquainted with new achievements in the field of inverse problems, communicating with the participants of the seminar, but also can take part in it as a speaker, if they get new results. At the same time, students independently acquire experience and skills of research of inverse problems, performances before sometimes eminent scientists who can ask various questions to which it is necessary to be able to give the reasonable answer; they have an interest in problems of research of inverse problems. Already from the student years they are involved in research work in the field of inverse problems for differential equations.

Students work on course and final qualifying works on inverse problems for differential equations. As topics of such student research papers, students are encouraged to explore generally applied problems that are not outlined in the training courses on inverse problems for differential equations. Therefore, students need to work independently with special literature, namely scientific articles, materials of scientific conferences, monographs; attend scientific seminars. There are cases when students receive new results, which are later published in various publications. The appearance of the first publications in the student years for them is very difficult to overestimate. Subsequently, students become highly qualified specialists, and some of them become candidates and doctors of Sciences.

Participation of students in student scientific conferences. On the basis of some Russian classical universities organized student scientific conferences, which are attended by students, postgraduates, young scientists. For example, on the basis of Novosibirsk state 
University in Soviet times was organized all-Union student scientific conference "Student and scientific and technological progress", which was attended by students and postgraduates of the Soviet Union. In further she has become all-Russian. It has sections in various directions, which are headed by candidates and doctors of Sciences. Before the beginning of the conference, the participants are usually made by well-known scientists, namely, academics, doctors, professors. At this conference reports are made on inverse problems for differential equations. As a result of the conference, the best reports are noted, which are recommended for printing.

Of course, the students participating in the conference, there is interest in further research, gaining experience in speech to the audience, communication not only with their peers, but also with venerable scientists. Students participating in such conferences have the opportunity to demonstrate their results not only to other participants of the conference, but also to the organizers of these conferences, who are present during their speech. In some cases, this can play an important role for students in their further research. For example, a student, if he / she is a graduate of the University, may be offered further training in graduate school, in which he / she will engage in research work on the proposed research topic; advise to engage in research on a specific topic and further maintain scientific relationships.

Of course, the students participating in the conference, there is interest in further research, gaining experience in speech to the audience, communication not only with their peers, but also with venerable scientists. Students participating in such conferences have the opportunity to demonstrate their results not only to other participants of the conference, but also to the organizers of these conferences, who are present during their speech. In some cases, this can play an important role for students in their further research. For example, such a student can be offered further training in graduate school, in which he will be engaged in research work on the proposed research topic; advise to engage in research on a specific topic and further maintain scientific relationships.

The author of this article had the honor to take part in it during his student years and can say with confidence that such student conferences play an important role for students engaged in research work, including in the field of inverse problems for differential equations. There is not only confidence in their own ability, but also an interest in further studies to gain the experience of communicating scientific interests, expanding horizons in a specific scientific area, which conducts its own studies, there may be a range of scientific Dating, which is important in research work, etc.

Writing essays by students based on scientific articles on inverse problems for differential equations. In the process of learning inverse problems for differential equations, students, as an independent work, it is proposed to read a scientific article and write a summary on it. This may be due to the small amount of hours allocated to the curriculum for a particular course of choice, which makes it impossible to consider in the classroom a particular inverse problem. But from the point of view of the integrity of training, professional orientation of training it is useful to know the students. This can also be the case when a student has a great interest in inverse problems for differential equations.

In these cases, when working on the abstract, students gain experience of independent work with special literature on inverse problems for differential equations, get used to the style of presentation of the material in scientific publications, which is much more difficult 
than in teaching materials addressed to students; get acquainted with the method of solving this inverse problem, which is not found in the content of learning inverse problems.

Participation of students in research work. Students who show great interest in inverse problems for differential equations, it is advisable to involve in specific scientific projects on inverse problems. This practice is implemented in the departments existing on the basis of research institutes, for example, at the Moscow state University named after M.V. Lomonosova, Moscow Institute of physics and technology, Moscow state technical University named after N.E. Bauman, Novosibirsk national research state University and other universities. As a result, students are involved in research work, which in the future can play an important role both in teaching inverse problems, and in their further professional activities in the field of applied research.

In the process of independent work in the study of inverse problems for differential equations, students learn not only mathematical methods for solving inverse problems, but also gain experience in the construction and analysis of mathematical models of inverse problems, bringing them to a form convenient for research. Independent work contributes to the formation of students' scientific Outlook, understanding of scientific and educational and humanitarian potential of inverse problems, the awareness of gnoseological processes in applied mathematics.

\section{LITERATURE}

[1] Алонцева Е.А., Гилев А.A. Межпредметные связи естественнонаучных и общетехнических дисциплин // Вестник Самарского государственного технического университета. Серия «Психолого-педагогические науки». 2011. № 1. С. 9-13.

[2] Бидайбеков Е.Ы., Корнилов В.С., Камалова Г.Б. Обучение будущих учителей математики и информатики обратным задачам для дифференциальных уравнений // Вестник Московского городского педагогического университета. Серия «Информатика и информатизация образования». 2014. № 3 (29). С. 57-69.

[3] Блехман И.М., Мышкис А.Д., Пановко Я.Г. Прикладная математика: Предмет, логика, особенности подходов. М.: КомКнига, 2005. 376 с.

[4] Бухгейм А.Л. Введение в теорию обратных задач. Новосибирск: Наука, Сибирское отделение, 1988. $181 \mathrm{c.}$

[5] Веселова Е.А. Формирование научного мировоззрения студентов в образовательно-воспитательном процессе высшей школы: дисс. ... канд. пед. наук. Нижний Новгород, 2008. $255 \mathrm{c}$.

[6] Волгин Н.А., Одегов Ю.Г., Ракитский Б.В., Хорзов С.Е. и др. Организация, формы и методы проведения учебных занятий и самостоятельной работы: требования, условия, механизмы: учеб.-метод. пособие. М.: РЭА, 2004. 88 с.

[7] Корнилов В.С. О междисциплинарном характере исследований причинно-следственных обратных задач // Вестник Московского городского педагогического университета. Серия «Информатика и информатизация образования». 2004. № 1 (2). С. 80-83.

[8] Корнилов B.C. Некоторые обратные задачи идентификации параметров математических моделей: учеб. пособие. М.: МГПУ, 2005. 359 с.

[9] Корнилов B.C. Гуманитарная компонента прикладного математического образования // Вестник Московского городского педагогического университета. Серия «Информатика и информатизация образования». 2006. № 2 (7). С. 94-100.

[10] Корнилов В.С. Психологические аспекты обучения студентов вузов фрактальным множествам // Вестник Российского университета дружбы народов. Серия: Информатизация образования. 2011. № 4. С. 79-82. 
[11] Корнилов В.С. Лабораторные занятия как форма организации обучения студентов фрактальным множествам // Вестник Московского городского педагогического университета. Серия «Информатика и информатизация образования». 2012. № 1 (23). С. 60-63.

[12] Корнилов B.C. Обратные задачи в учебных дисциплинах прикладной математики // Вестник Московского городского педагогического университета. Серия «Информатика и информатизация образования». 2014. № 1 (27). С. 60-68.

[13] Корнилов B.C. Обучение студентов обратным задачам математической физики как фактор формирования фундаментальных знаний по интегральным уравнениям // Бюллетень лаборатории математического, естественнонаучного образования и информатизации. Рецензируемый сб. науч. тр. Самара: Самарский филиал МГПУ, 2015. Т. VI. С. 251-257.

[14] Корнилов B.C. Обучение студентов обратным задачам для дифференциальных уравнений как фактор формирования компетентности в области прикладной математики // Вестник Российского университета дружбы народов. Серия: Информатизация образования. 2015. № 1. C. 63-72.

[15] Корнилов B.C. Реализация научно-образовательного потенциала обучения студентов вузов обратным задачам для дифференциальных уравнений // Казанский педагогический журнал. 2016. № 6. С. 55-59.

[16] Корнилов B.C. Теория и методика обучения обратным задачам для дифференциальных уравнений: монография. М.: Изд-во «ОнтоПринт», 2017. 500 с.

[17] Корнилов B.C. Формирование фундаментальных знаний по математическому моделированию при обучении обратным задачам для дифференциальных уравнений // Вестник Московского городского педагогического университета. Серия «Информатика и информатизация образования». 2017. № 1 (39). С. 92-99.

[18] Корнилов B.C. Обучение обратным задачам для дифференциальных уравнений как фактор развития научно-познавательного потенциала студентов // Вестник Московского городского педагогического университета. Серия «Информатика и информатизация образования». 2017. № 3 (41). С. 26-32.

[19] Корнилов B.C. Философская составляющая научно-образовательного потенциала обучения обратным задачам математической физики // Вестник Московского городского педагогического университета. Серия «Информатика и информатизация образования». 2018. № 1 (43). С. 59-65.

[20] Левченко И.В., Корнилов В.С., Беликов В.В. Роль информатики в подготовке специалистов по прикладной математике // Вестник Московского городского педагогического университета. Серия «Информатика и информатизация образования». 2009. № 2 (18). С. 108 112.

[21] Меренков А.В., Куньщиков С.В., Гречухина Т.И., Усачева А.В., Вороткова И.Ю. Самостоятельная работа студентов: виды, формы, критерии оценки. Екатеринбург: УГУ, 2016. 80 с.

[22] Романов В.Г. Обратные задачи математической физики. М.: Наука, 1984. 264 с.

[23] Самарский А.А., Вабишевич П.Н. Численные методы решения обратных задач математической физики. М.: УРСС, 2004. 478 с.

[24] Уваровская O.В., Краева И.Ю. Самостоятельная работа студентов: учеб.-метод. пособие. Сыктывкар: СыктГУ, 2009. 30 с.

Kornilov V.S., 2018

\section{Article history:}

Received: 19 January, 2018

Accepted: 24 February, 2018

\section{For citation:}

Kornilov V.S. (2018). The organization of independent work students when teaching inverse problems for differential equations. RUDN Journal of Informatization Education, 15 (2), 174-181. DOI 10.22363/2312-8631-2018-15-2-174-181 


\title{
Bio Note:
}

Kornilov Viktor Semenovich, doctor of pedagogical sciences, candidate of physical and mathematical sciences, full professor, deputy head of the department of informatization of education of the Moscow city pedagogical university. Contact information: e-mail: vs_kornilov@mail.ru

\section{ОРГАНИЗАЦИЯ САМОСТОЯТЕЛЬНОЙ РАБОТЫ СТУДЕНТОВ ПРИ ОБУЧЕНИИ ОБРАТНЫМ ЗАДАЧАМ ДЛЯ ДИФФЕРЕНЦИАЛЬНЫХ УРАВНЕНИЙ}

\author{
В.С. Корнилов \\ Московский городской педагогический университет \\ Шереметьевская ул., 29, Москва, Россия, 127521
}

В статье отмечается, что внеаудиторная самостоятельная работа вносит большой вклад в развитие научно-познавательного потенциала студентов в процессе обучения обратным задачам для дифференциальных уравнений. В процессе самостоятельной работы студентами не только прорабатывается учебный и научный материал по обратным задачам, даваемый на учебных занятиях, но и изучается специальная научная литература, т.е. научные статьи, материалы научных конференций, опубликованные не только на русском, но и на английском языке. При этом студенты осваивают научный стиль изложения научного материала в такой специальной литературе, который существенно отличается от стиля изложения учебного материала в вузовских учебниках. Отмечается, что во время самостоятельной работы студенты исследуют разнообразные обратные задачи, которые им рекомендованы преподавателем. Нарабатывают умения и навыки самостоятельно формулировать логические выводы по результатам исследования обратных задач.

Ключевые слова: обучение обратным задачам для дифференциальных уравнений, самостоятельная работа студентов, математические творческие способности студентов, научнопознавательный потенциал студентов

\section{REFERENCES}

[1] Alontseva E.A., Gilev A.A. Mezhpredmetnye svyazi estestvennonauchnyh i obshchetekhnicheskih disciplin [Interdisciplinary connections of the Sciences and the technical disciplines]. Vestnik Samarskogo gosudarstvennogo tekhnicheskogo universiteta. Serija «Psihologo-pedagogicheskie nauki» [Bulletin of Samara state technical University. "Psychological and pedagogical Sciences" series]. 2011. No. 1. Pp. 9-13.

[2] Bidaibekov E.S., Kornilov V.S., Kamalova G.B. Obuchenie budushhih uchitelej matematiki $i$ informatiki obratnym zadacham dlja differencial'nyh uravnenij [The training of future teachers of mathematics and Informatics inverse problems for differential equations]. Vestnik Moskovskogo gorodskogo pedagogicheskogo universiteta. Serija «Informatika i informatizacija obrazovanija» [Bulletin of the Moscow city pedagogical university. "Informatics and Informatization of Education" series]. 2014. No. 3 (29). Pp. 57-69.

[3] Blehman I.M., Myshkis A.D., Panovko Ja.G. Prikladnaja matematika:predmet, logika, osobennosti podhodov [Applied mathematics: the subject of logic, especially the approaches]. M.: KomKniga, 2005. $376 \mathrm{p}$.

[4] Buhgejm A.L. Vvedenie v teoriju obratnyh zadach [Introduction to the theory of inverse problems]. Novosibirsk: Nauka, Sibirskoe otdelenie, 1988. 181 p. 
[5] Veselova E.A. Formirovanie nauchnogo mirovozzreniya studentov v obrazovatel'no-vospitatel'nom processe vysshej shkoly [Formation of scientific Outlook of students in educational process of higher school]: diss. ... kand. ped. nauk. Nizhnij Novgorod, 2008. 255 p.

[6] Volgin N.A., Odegov Yu.G., Rakitskij B.V., Horzov S.E., etc. Organizaciya, formy i metody provedeniya uchebnyh zanyatij $i$ samostoyatel'noj raboty: trebovaniya, usloviya, mekhanizmy [Organization, forms and methods of training and self-study: requirements, conditions, mechanisms]: uchebno-metodicheskoe posobie. M.: REA, 2004. 88 p.

[7] Kornilov V.S. O mezhdisciplinarnom haraktere issledovanij prichinno-sledstvennyh obratnyh zadach [About cross-disciplinary character of researches of cause and effect inverse problems]. Vestnik Moskovskogo gorodskogo pedagogicheskogo universiteta. Serija «Informatika i informatizacija obrazovanija» [Bulletin of the Moscow city pedagogical university. "Informatics and Informatization of Education" series]. 2004. No. 1 (2). Pp. 80-83.

[8] Kornilov V.S. Nekotorye obratnye zadachi identifikacii parametrov matematicheskih modelej [Some inverse problem of identifying parameters of mathematical models]: uchebnoe posobie. M.: MGPU, 2005. $359 \mathrm{p}$.

[9] Kornilov V.S. Gumanitarnaya komponenta prikladnogo matematicheskogo obrazovaniya [Humanitarian component of mathematical education]. Vestnik Moskovskogo gorodskogo pedagogicheskogo universiteta. Serija «Informatika i informatizacija obrazovanija» [Bulletin of the Moscow city pedagogical university. "Informatics and Informatization of Education" series]. 2006. No. 2 (7). Pp. 94-100.

[10] Kornilov V.S. Psihologicheskie aspekty obuchenija studentov vuzov fraktal'nym mnozhestvam [Psychological aspects of training of students of higher education institutions in fractal sets]. Vestnik Rossijskogo universiteta druzhby narodov. Serija «Informatizacija obrazovanija» [Bulletin of the Russian university of friendship of the people. "Education Informatization" series]. 2011. No. 4. Pp. 79-82.

[11] Kornilov V.S. Laboratornye zanjatija kak forma organizacii obuchenija studentov fraktal'nym mnozhestvam [Laboratory sessions as a form of organization of teaching students fractal sets]. Vestnik Moskovskogo gorodskogo pedagogicheskogo universiteta. Serija «Informatika i informatizacija obrazovanija» [Bulletin of the Moscow city pedagogical university. "Informatics and Informatization of Education" series]. 2012. No. 1 (23). Pp. 60-63.

[12] Kornilov V.S. Obratnyye zadachi v uchebnykh distsiplinakh prikladnoy matematiki [Inverse problems in the disciplines of applied mathematics]. Vestnik Moskovskogo gorodskogo pedagogicheskogo universiteta. Serija «Informatika i informatizacija obrazovanija» [Bulletin of the Moscow city pedagogical university. "Informatics and Informatization of Education” series]. 2014. No. 1 (27). Pp. 60-68.

[13] Kornilov V.S. Obuchenie studentovobratnym zadacham matematicheskojfiziki kak factor formirovanija fundamental'nyh znanij po integral'nym uravnenijam [Training of students in the inverse problems of mathematical physics as factor of formation of fundamental knowledge of the integrated equations]. Bjulleten' laboratorii matematicheskogo, estestvennonauchnogo obrazovanija $i$ informatizacii. Recenziruemyj sbornik nauchnyh trudov [Bulletin of laboratory of mathematical, natural-science education and informatization. The reviewed collection of scientific work]. Samara: Samarskij filial MGPU, 2015. T. VI. Pp. 251-257.

[14] Kornilov V.S. Obuchenie studentov obratnym zadacham dlja differencial'nyh uravnenij kak factor formirovanija kompetentnosti voblasti prikladnoj matematiki [Students learning the inverse problems for differential equations as a factor of formation of competence in the field of applied mathematics]. Vestnik Rossijskogo universiteta druzhby narodov. Serija «Informatizacija obrazovanija» [Bulletin of the Russian university of friendship of the people. "Education Informatization" series]. 2015. No. 1. Pp. 63-72.

[15] Kornilov V.S. Realizacija nauchno-obrazovatel'nogo potenciala obuchenija studentov vuzovobratnym zadacham dlja differencial'nyh uravnenij [Realization of scientific and educational potential of training of students of higher education institutions in the inverse problems for the differential equations]. Kazanskij pedagogicheskij zhurnal [Kazan pedagogical journal]. 2016. No. 6. Pp. 5559. 
[16] Kornilov V.S. Teorija i metodika obuchenija obratnym zadacham dlja differencial'nyh uravnenij [Theory and technique of training to the inverse problems for differential equations]: monografija. M.: Izd-vo «OntoPrint», 2017. 500 p.

[17] Kornilov V.S. Formirovanie fundamental'nyh znanij po matematicheskomu modelirovaniju pri obuchenii obratnym zadacham dlja differencial'nyh uravnenij [Formation of fundamental knowledge of mathematical modeling when training in the return tasks for the differential equations]. Vestnik Moskovskogo gorodskogo pedagogicheskogo universiteta. Serija «Informatika i informatizacija obrazovanija» [Bulletin of the Moscow city pedagogical university. "Informatics and Informatization of Education" series]. 2017. No. 1 (39). Pp. 92-99.

[18] Kornilov V.S. Obuchenie obratnym zadacham dlja differencial'nyh uravnenij kak faktor razvitija nauchno-poznavatel'nogo potenciala studentov [Learning inverse problems for differential equations as a factor of development of scientific and cognitive potential of students]. Vestnik Moskovskogo gorodskogo pedagogicheskogo universiteta. Serija «Informatika i informatizacija obrazovanija» [Bulletin of the Moscow city pedagogical university. "Informatics and Informatization of Education" series]. 2017. No. 3 (41). Pp. 26-32.

[19] Kornilov V.S. Filosofskaya sostavlyayushchaya nauchno-obrazovatel'nogo potenciala obucheniya obratnym zadacham matematicheskoj fiziki [Philosophical component of scientific and educational potential of learning inverse problems of mathematical physics]. Vestnik Moskovskogo gorodskogo pedagogicheskogo universiteta. Serija «Informatika i informatizacija obrazovanija» [Bulletin of the Moscow city pedagogical university. "Informatics and Informatization of Education" series]. 2018. No. 1 (43). Pp. 59-65.

[20] Levchenko I.V., Kornilov V.S., Belikov V.V. Rol' informatiki v podgotovke specialistov po prikladnoj matematike [The role of Informatics in the training of specialists in applied mathematics]. Vestnik Moskovskogo gorodskogo pedagogicheskogo universiteta. Serija «Informatika i informatizacija obrazovanija» [Bulletin of the Moscow city pedagogical university. "Informatics and Informatization of Education" series]. 2009. No. 2 (18). Pp. 108-112.

[21] Merenkov A.V., Kundikov S.V., Grechuhina T.I., Usacheva A.V., Vorotkova I.Yu. Samostoyatel'naya rabota studentov: vidy, formy, kriterii ocenki [Independent work of students: types, forms, evaluation criteria]. Yekaterinburg: UGU, 2016. 80 p.

[22] Romanov V.G. Obratnye zadachi matematicheskojfiziki [Inverse problems of mathematical physics]: monografija. M.: Nauka, 1984. 264 p.

[23] Samarskij A.A., Vabishevich P.N. Chislennye metody reshenija obratnyh zadach matematicheskoj fiziki [Numerical methods of the solution of the inverse problems of mathematical physics]: monografija. M.: Editorial URSS, 2004. 480 p.

[24] Uvarovskaya O.V., Kraeva I.YU. Samostoyatel'naya rabota studentov [Independent work of students]: uchebno-metodicheskoe posobie. Syktyvkar: SyktGU, 2009. 30 P.

\section{История статьи:}

Дата поступления в редакцию: 19 января 2018

Дата принятия к печати: 24 февраля 2018

\section{Для цитирования:}

Корнилов B.C. Организация самостоятельной работы студентов при обучении обратным задачам для дифференциальных уравнений // Вестник Российского университета дружбы народов. Серия «Информатизация образования». 2018. Т. 15. № 2. С. 174-181. DOI 10.22363/2312-8631-2018-15-2-174-181

\section{Сведения об авторе:}

Корнилов Виктор Семенович, доктор педагогических наук, кандидат физико-математических наук, профессор, заместитель заведующего кафедрой информатизации образования Московского городского педагогического университета. Контактная информация: e-mail: vs_kornilov@mail.ru 